\title{
Antepartum haemorrhage: a retrospective analysis in a tertiary care centre
}

\author{
Mohini Rajoriya ${ }^{1}$, Saurabh Dubey ${ }^{2}$, Sanju Agarwal ${ }^{1 *}$
}

\begin{abstract}
${ }^{1}$ Department of Obstetrics and Gynaecology, ${ }^{2}$ Department of Dermatology, Mahatma Gandhi Medical College and Maharaja Yashwant Roa Hospital, Indore, Madhya Pradesh, India
\end{abstract}

Received: 21 August 2020

Revised: 04 October 2020

Accepted: 05 October 2020

\author{
*Correspondence: \\ Dr. Sanju Agarwal, \\ E-mail: sanjugrmc@gmail.com
}

Copyright: (c) the author(s), publisher and licensee Medip Academy. This is an open-access article distributed under the terms of the Creative Commons Attribution Non-Commercial License, which permits unrestricted non-commercial use, distribution, and reproduction in any medium, provided the original work is properly cited.

\begin{abstract}
Background: Aim of the present study was to found the incidence of APH, demographic profile risk factors and maternal outcome.

Methods: This was a retrospective study carried out in Department of Obstetrics and Gynaecology, MGM Medical College and associated M.Y., Hospital, Indore from August 2019 to July 2020.

Results: The incidence of APH was 3.27\%. 68.7\% cases of APH were associated with pregnancy induced hypertension suggesting PIH is one of the major risk factors. Maternal morbidity was very high with increased rates cesarean section $91.7 \%$, postpartum hemorrhage (32.6\%), need of blood transfusion (86\%). There were 2 mortalities and $3.1 \%$ patients underwent Obstetric Hystrectomy and 24\% required CCU admission.

Conclusions: There is very high maternal morbidity and mortality in APH.
\end{abstract}

Keywords: Antepartum hemorrhage, Maternal morbidity, Maternal mortality

\section{INTRODUCTION}

Antepartum haemorrhage is an Obstetric emergency contributing to a significant amount of perinatal and maternal morbidity and mortality. APH complicates about $2-5 \%$ of all the pregnancies with incidence of placenta praevia (PP) about $0.33 \%$ to $0.55 \%$ and incidence of abruptio placenta (AP) about $0.5-1 \%$. Thirty percent of maternal deaths are caused by antepartum haemorrhage of which $50 \%$ are associated with avoidable factors. ${ }^{1}$ Antepartum haemorrhage is defined as any bleeding from or into the genital tract after 28 weeks of gestation and before the period of viability. Antepartum haemorrhage quantified as minor haemorrhage: blood loss $<50 \mathrm{ml}$; major haemorrhage: blood loss 50-1000 ml; massive haemorrhage: blood loss $>1000 \mathrm{ml}$. The causes of antepartum hemorrhage can be divided into three main groups, placenta previa, placental abruption and others.
Placenta previa exists when the placenta is implanted wholly or in part into the lower segment of the uterus. An abruption placentae is the condition whenever bleeding occurs due to premature separation of a normally sited placenta. Other causes are cervical polyp, cervical carcinoma local lesions of vagina and cervix. Systemic diseases like leukemia and bleeding disorders are rare causes of APH. Placenta praevia and abruptio placentae account for almost half cases of APH. ${ }^{2}$

Maternal complications of APH are malpresentation, premature labour, postpartum hemorrhage, shock, retained placenta. They also include higher rates of caesarian section, peripartum hysterectomy, coagulation failure, puerperal infections and even death ${ }^{3}$ In developing countries like India, women frequently experience adverse effects of obstetric haemorrhage due to widespread pre-existing anaemia, difficulties with 
transport and overwhelming inadequacies of maternity services. $^{4}$

Objective of the study was to study the incidence of antepartum hemorrhage at Tertiary care hospital, to study the maternal outcome in antepartum haemorrhage and to study the associated risk factors contributing to maternal morbidity and mortality.

\section{METHODS}

This was a retrospective study done at Department of Obstetrics and Gynaecology, MGM Medical College and associated M.Y. Hospital, Indore, India from August 2019 to July 2020.

All cases of APH with gestational age more than 28 week who were admitted in the hospital during study period were included in the study. A list of all patients that had APH from August 2019 to July 2020 was compiled from labor ward and the case papers were then retrieved from the Medical Records Department of the hospital. Patients whose case papers could not be traced were excluded from the study. The total number of deliveries during the study period was also obtained. Data relating to etiology, age, educational status, parity, booking status, gestational age at presentation, mode of delivery, and the maternal outcome were extracted and entered into a questionnaire designed for the study.

Ethical approval was obtained from the institutional ethics and research committee prior to commencement of study

\section{Statistical analysis}

Data was analysed and presented in tabular form in percentage.

\section{RESULTS}

During the one-year study period involving 386 women with a diagnosis of APH, The following results were obtained.

\section{Maternal outcome}

The incidence APH was $3.27 \%$. Placenta previa is $0.81 \%$ and that of abruptio placentae is $2.41 \%$. The incidence of APH was $51.2 \%$ in the age group 26-30 years and $31 \%$ in age 21-25 years. Sixty nine percent of cases of APH were multigravida. $48 \%$ of whom were gravida 3 and gravida 4. 108 cases $(27.9 \%)$ had a history of previous uterine surgery. I96 out of 285 cases of abruption associated with pregnancy induced hypertension. Out of 386 cases who presented with APH, 354 patients (91.7\%) delivered by Caesarean section and the remaining $32(8.2 \%)$ delivered vaginally. In the present study, there were 2 mortalities. 32.6 percent were complicated by $\mathrm{PPH}$. Out of total number of women presenting with APH (386), 332 required blood and blood products transfusion $(86 \%)$.
For control of PPH, other operative interventions such as vessel ligation, placental bed suturing, packing of lower uterine segment were used. Caesarean hysterectomy was done in 12 cases $(3.1 \%)$ for intractable haemorrhage.

Table 1: Causes of APH.

\begin{tabular}{|ll|}
\hline Causes & No. of patient \\
\hline Placenta previa & 96 \\
\hline Abruptio placentae & 285 \\
\hline Undetermined & 5 \\
\hline
\end{tabular}

Table 2: Incidence of APH.

\begin{tabular}{|c|c|}
\hline Risk factors & Number \\
\hline $\begin{array}{l}\text { Total no of deliveries in } 1 \\
\text { years }\end{array}$ & 11801 \\
\hline Incidence of APH & $3.27 \%$ \\
\hline Incidence of placenta. previa & $0.81 \%$ \\
\hline $\begin{array}{l}\text { Incidence of abruptio. } \\
\text { placentae }\end{array}$ & $2.41 \%$ \\
\hline
\end{tabular}

Table 3: Demographic parameters of patients.

\begin{tabular}{|llll|}
\hline Parameters & & Number & \multicolumn{1}{c}{$\begin{array}{c}\text { Percentage } \\
(\%)\end{array}$} \\
\hline \multirow{3}{*}{ Age (years) } & $<20$ & 22 & 5.6 \\
\cline { 2 - 4 } & $21-25$ & 120 & 31.08 \\
\cline { 2 - 4 } & $26-30$ & 198 & 51.29 \\
\cline { 2 - 4 } Parity & $>30$ & 46 & 11.9 \\
\hline \multirow{2}{*}{ Gestational age } & Primigravida & 118 & 30.56 \\
\cline { 2 - 4 } & Multigravida & 268 & 69.43 \\
\cline { 2 - 4 } & $\mathbf{3} 34$ weeks & 183 & 47.4 \\
\hline
\end{tabular}

Table 4: Risk factors associated with APH.

\begin{tabular}{|ll|}
\hline Risk factors & No. of Patient (\%) \\
\hline $\begin{array}{l}\text { Hypertensive disorder of } \\
\text { pregnancy ( abruption) }\end{array}$ & $196 / 285$ ( 68.7) \\
\hline History of cesaerean section & $108(27.9)$ \\
\hline
\end{tabular}

Table 5: Maternal complications.

\begin{tabular}{|lll|}
\hline Maternal complications & Number & Percentage \\
\hline $\begin{array}{l}\text { Post partum } \\
\text { hemorrhage }\end{array}$ & 126 & $32.60 \%$ \\
\hline Cesaerean delivery & 354 & $91.7 \mathrm{Kg}$. \\
\hline Blood transfusionn & 332 & $86.01 \%$. \\
\hline $\begin{array}{l}\text { Peripartum } \\
\text { hystrectomy }\end{array}$ & 12 & $3.10 \%$ \\
\hline ICU Admission & 93 & 24 \\
\hline Death & 2 & 0.51 \\
\hline
\end{tabular}




\section{DISCUSSION}

The incidence of APH reported from this study is $3.27 \%$, while it is quoted to be $2-5 \%, 2.01 \%$ and $2.53 \%$ in other studies from other parts of the world. The incidence observed at Siriraj Hospital, Thailand in 1985 was found to be $0.6 \%$ while Arora et al from India reported the incidence of $2.53 \% .^{5,6}$

Mean age of patients presented with APH in this study is 26-30 years which is similar to the result reported by Das et al, Abbasi et al also reported the mean age 30 years in a study from tertiary care hospital in Sindh. ${ }^{6,7}$ Incidence of APH is more in multigravida $(69.4 \%)$ than in primigravida $(30.5 \%)$ in our study. Other studies such as Gillium et al and Clark et al have also reported high incidence of APH in multipara which was about 5-8 times higher than primigravida thus confirming the role of endometrial damage caused by repeated childbirth, a risk factor for uteroplacental bleeding in pregnancy. ${ }^{8,9}$ Scarring of uterus due to previous uterine surgery stands out as a one of the major etiological factors for APH, more specifically placentprevia. In the present study, $27 \%$ (108/386) cases presented with APH had history of previous uterine surgery in the form of caesarean section, In the present study, 196 out of $285(68 \%)$ cases were associated with pregnancy induced hypertension suggesting it is one of the major risk factors for abruption resulting in APH. This is comparable to the study of Bryan et al.10 which suggested that Pre-eclampsia is an etiological factor in $80 \%$ cases of placental abruption.

The incidence of caesarean section in present study is $91.7 \%$. The incidence of caesarean section in placenta previa group is $100 \%$ similar to the study done by Khouri et al. ${ }^{11}$ The incidence of caesarean in the abruption placentae group in the present study is $88.7 \%$ while that reported by Hurd et al from the UK and the study reported by Rochelle et al at Washington State were 50\% and $37.9 \%$ respectively. ${ }^{12,13}$

In the present study, there were $2(0.51 \%)$ mortalities. Both patients has grade 4 abrubtion placentae and died due to renal failure. Gorodeski et al reported maternal mortality of $0.46 \%$ in APH while Pedowitz et al reported it as $0.9 \% .{ }^{14,15}$ Cotton et al found no mortality in cases of PP in their study. ${ }^{16}$ Thirty two percent of these cases were complicated by PPH. The commonest cause of PPH was uterine atony followed by coagulation failure. Crane et al reported the incidence of PPH in APH to be $19 \% .{ }^{17}$ In this study $86 \%$ of patients required blood transfusion. Brenner et al reported the incidence of blood transfusion as $36 \%$ and $52.4 \%$ respectively. ${ }^{18}$ The very high rates of blood transfusion in the present study might be due to the reason that most of the patients were already anaemic at the time of admission. Twelve patients (3\%) required caesarean hysterectomy and 93 patients $(24 \%)$ required CCU admission.

\section{CONCLUSION}

In conclusion, there was very high maternal morbidity with increased rates of anaemia, postpartum haemorrhage, blood and blood products transfusion, caesarean section rates, preterm deliveries and prolonged post-operative stay. Clinical care should therefore concentrate on prevention, early detection and prompt management. Furthermore, pregnant women with APH should be considerd high risk and timely management should be offered.

Funding: No funding sources

Conflict of interest: None declared

Ethical approval: The study was approved by the Institutional Ethics Committee

\section{REFERENCES}

1. Miller DA. Treatment of antepartum haemorrhage. Womens and children's Hospital, Department of obstetrics and Gynaecology, Los Angeles, USA.

2. Nicholas N, Bhide A. Antepartum haemorrhage. Current Obst Gynaecol. 2006;16(2):79-83.

3. Dutta DC. Antepartum hemorrhage. In: Konar HL, editor. Textbook of Obstetrics. 6th ednition. Kolkata, India: New central book agency. 2006:243-246.

4. Harrison KA. Maternal mortality. Brt J Obstet Gynecol. 1985;5:100-15.

5. Arora R, Devi U, Majumdar R. Perinatal morbidity and mortality in antepartum haemorrhage. $\mathrm{J}$ Obstet Gynecol India. 2001;51(30):102-4.

6. Das B. Antepartum haemorrhage in three decades. J Obstet Gynaecol India. 1978;25:636-7.

7. Abbasi RM, Rizwan N, Farooq S. Fetomaternal outcome among abruption placenta cases at a University hospital of Sindh. J Liaquat Uni Med Health Sci. 2008;7(2):106-9.

8. Gilliam M, Rosenberg D, Davis F. The likelihood of placenta praevia with greater number of cesarean deliveries and higher parity. Obstet Gynecol. 2002;99(6):976-80.

9. Clark SL, Koonings PP, Phelan JP. Placenta previa/ Accreta and prior Caesarean section. Obstet Gynecol. 1985;66(1):89-92.

10. Hibbard BM. Abruptio Placentae, pre eclampsia, and essential hypertension. BJOG. 1962;69(2):282-7.

11. Khouri JA, Sultan MG. Previous caesarean section and the rising incidence of placenta previa and placenta accrete. J Obstet Gynecol. 1994;14(1):14-6.

12. Hurd WW, Miodovnik M, Hertzberg V. Selective management of abruptio placenta: a prospective study. Obstet Gynecol. 1983;61(4):467-33.

13. Rochelle LM, Holt VL, Easterling TR. First birth caesarean and placental abruption or previa at second birth. J Obstet Gynecol. 2001;97(5):765-9.

14. Gorodeski IG, Bahari CM, Schachter A. Recurrent placenta previa. Eur J Obst Gynecol Reprod Biol. 1981;12(1):7-11. 
15. Pedowitz P. Placenata previa an evaluation of expectant management and the factors responsible for fetal wastage. Am J Obstet Gynecol. 1965;93:16-25.

16. Cotton DB, Read JA, Paul RH. The conservative aggressive management of placenta previa. Am J Obst Gynecol. 1980;137(6):687-95.

17. Crane JM, Hof MC, Dodds L. Neonatal outcome with placenta previa. Obstet Gynaecol. 1999;93(4):541-4.
18. Brenner WF, Edelman PA, Hendriches $\mathrm{CH}$. Characteristics of patients with placenta previa and results of expectant management. Am J Obstet Gynecol. 1978;132(2):180-4.

Cite this article as: Rajoriya M, Dubey S, Agarwal $\mathrm{S}$. Antepartum haemorrhage (APH): a retrospective analysis in a tertiary care centre. Int J Reprod Contracept Obstet Gynecol 2020;9:4531-4. 